UDC 616.127-005.8-059-06-092.12

DOI: 10.21668/health.risk/2019.1.15.eng

Read

\title{
PATIENT AFTER CARDIAC INFARCTION: RISK FACTORS THAT CAN CAUSE NEW CARDIOVASCULAR DISASTERS
}

\author{
I.A. Novikova, L.A. Nekrutenko, T.M. Lebedeva, O.V. Kchlynova, E.A. Shishkina \\ E.A. Vagner's Perm State Medical University of the RF Public Healthcare Ministry, 26 Petropavlovsjaya Str., \\ Perm, 614000, Russian Federation
}

\begin{abstract}
Over recent years there has been a trend for a decrease in lethality during an acute cardiac infarction period; but at the same time there is a growth in a number of patients who run high risks of recurrent adverse cardiovascular events. Despite secondary prevention measures having been introduced, frequency of recurrent cardiac infarctions is still high, and most of them occur during the first year. Our research goal was to reveal basic risk factors that cause recurrent adverse cardiovascular events in patients during the first year after a cardiac infarction. We questioned 40 patients living in Perm who had had cardiac infractions from September 2017 to July 2018 and who were undergoing polyclinic rehabilitation. To perform this questioning, we applied an original questionnaire.

We revealed that men prevailed among patients with cardiac infarction. The first infarction usually occurs in early 60ties. Ischemic heart disease starts with cardiac infarction in $45 \%$ patients. We detected that at least one risk factor occurred for all the patients; the most widely spread risk factors in the given population were burdened heredity, low physical activity, overweight, uncontrolled arterial hypertension, and hypercholesterolemia. We also revealed in our research that less than $50 \%$ patients were committed to treatment and it was primarily due to low awareness about the necessity to take medications and also due to these medications being hardly affordable for patients. Therefore, patients who suffered from cardiac infarction and are undergoing polyclinic rehabilitation run an elevated risk of recurrent cardiovascular events during the first year and it means that secondary prevention measures are not efficient. When treating patients with cardiac infarction, we should optimize interaction between a physician and a patient and pay greater attention to a patient being committed to treatment.

Key words: cardiac infarction, recurrent cardiac infarction, risk factors, revascularization, rehabilitation, commitment to treatment, secondary prevention.
\end{abstract}

Cardiac infarction (CI) is the most severe type of ischemic heart disease (IHD). Nevertheless, there have been positive trends detected recently in treating patients with acute CI such as percutaneous coronary interventions (PCI) which are performed promptly and early application of antithrombocytic medications, betaadrenoceptor blocking drugs, inhibitors of angiotensin converting enzyme (ACE), and statins. It has led to a reduction in lethality that is observed at present [1-4]. However, longer life span and a growth in number of patients who have survived after their first CI results in greater risks of new cardiovascular disasters.
In spite of secondary prevention activities being implemented in significant scopes, frequency of recurrent CI still remains high. As per data provided by different authors, patients with recurrent CI account for $14-41.6 \%$ of the overall number of people who have been hospitalized with diagnosed CI [5-8]. Up to $40 \%$ of all recurrent CI occur during the first year [9]. As a rule, patients with recurrent $\mathrm{CI}$ run higher risks of unfavorable outcome [8, 10-11] due to a greater number of probable complications. Still, most scales showing CI risks usually give an idea of only a short-term forecast [12-14], and when such patients are provided with am-

(C) Novikova I.A., Nekrutenko L.A., Lebedeva T.M., Kchlynova O.V., Shishkina E.A., 2019

Irina A. Novikova - External Researcher at the Hospital Therapy Department (e-mail: Nurdus@yandex.ru; tel.: +7 (342) 239-31-88; ORCID: http://orcid.org/0000-0002-3968-6498).

Ludmila A. Nekrutenko - Doctor of Medicine, Professor at the Hospital Therapy Department (e-mail: lunekru@mail.ru; tel.: +7 (342) 239-31-88; ORCID: http://orcid.org/0000-0001-9151-8195).

Tatyana M. Lebedeva - Doctor of Medicine, Professor at the Department for Public Health and Healthcare (e-mail: super.oziz@yandex.ru; tel.: +7 (342) 236-12-56; ORCID: http://orcid.org/0000-0003-3374-8982).

Olga V. Kchlynova - Corresponding Member of the RAS, Doctor of Medicine, Professor, Head of the Hospital Therapy Department (e-mail:olgakhlynova@mail.ru; tel.: +7 (342) 239-31-88; ORCID: https://orcid.org/0000-0003-4860-0112).

Ekaterina A. Shishkina - Candidate of Medical Science, Associate Professor at the Hospital Therapy Department (e-mail:doctor.shishkina@yandex.ru; tel.: +7 (342) 239-31-88; ORCID: http://orcid.org/0000-0001-6965-7869). 
bulatory care, comparatively small attention is paid to assessing their risk factors [15].

As per data taken from an acute coronary syndrome (ACS) register in Kemerovo region [16], 26.5\% of all patients observed for 5 years had recurrent CI, $40 \%$ of all these disease cases occurred during the first year, and it confirms data provided by the Emergency Cardiology Department at Sklifosovskiy Research Institute of Emergency Care which are given above [9]. Recurrent CI resulted in fatal outcome in $18.4 \%$ cases. Authors spot out several risk factors that can cause recurrent $\mathrm{CI}$; they are age, poor education and low standard of living, hypodynamia, and multi-focal atherosclerosis. Patients with recurrent CI can have other risk factors such as family case history burdened with IHD (70\%), hypercholesterolemia $(60.8 \%)$, arterial hypertension $(68 \%)$, overweight or obesity (71.4\%), smoking (61.6\%), and pancreatic diabetes $(20.8 \%)$. However, there were no significant discrepancies as per most abovementioned parameters between patients with recurrent $\mathrm{CI}$ and those who had their first CI.

A prospective cohort study accomplished in Novosibirsk revealed that $31.7 \%$ recurrent CI also occurred during the first year [17]. Men prevailed among patients with recurrent CI (59.2\%); arterial hypertension occurred in 96.1\% cases; smoking, 38.8\%; heredity burdened as per arterial hypertension and IHD, $76.3 \%$ and $52.5 \%$ respectively; average level of total cholesterol amounted to $5.9 \pm 1.2 \mathrm{mmol} / \mathrm{l}$, average body mass index (BMI) was equal to $32.2 \pm 4.8 \mathrm{~kg} / \mathrm{m}^{2}$.

In Yakutia, risk factors prevalence also remains high among patients after their first CI. 12 months after CI $62.2 \%$ have hypercholesterolemia; $35.6 \%$, carbohydrate metabolism disorders; $26.7 \%$, BMI $\geq 30 \mathrm{~kg} / \mathrm{m}^{2}$; $75.6 \%$ have abdominal obesity, and $46.7 \%$ patients smoke [18].

Let's overview some foreign data. A study accomplished in Albania revealed that patients with recurrent CI more frequently suffered from heart failure, low ejection fraction of the left ventricle, and multi-vessel coronary artery disease [19]. They were less frequently given medications with a solid evidential base and underwent revascularization rather rarely. But overall, prevalence of risk factors (arterial hypertension, hypercholesterolemia) practically had no discrepancies in patients with recurrent CI and those with their first CI.

A study performed in China revealed some independent risk factors that could cause recurrent $\mathrm{CI}$; they were age, pancreatic diabetes, and reperfusion [20]. In-hospital lethality was higher among patients with recurrent CI.

We should note that some foreign researchers assess risk factors only for combined end points without separately spotting out recurrent CI. Thus, a study performed in Sweden called HELICON highlighted the following risk factors of unfavorable cardiovascular events in patients a year after CI: age (60 and older), pancreatic diabetes, heart failure, and a failure to conduct revascularization during CI [21].

So, most authors indicate several risk factors that can cause recurrent $\mathrm{CI}$; they are age, hypercholesterolemia, carbohydrate metabolism disorders, overweight, smoking, heart failure, and failure to conduct revascularization.

International recommendations on how to treat patients with CI include secondary prevention that involves changes in a lifestyle (giving up smoking, losing weight until BMI is within standards, etc.), taking statins, applying double antithrombocytic therapy, taking drugs that block renin-angiotensin-aldosterone system and beta-adrenoceptor blocking drugs. 4S, CARE and LIPID research revealed that when patients who had cardiac infarction in their case history took statins, it lead to a $30 \%$ decrease in lethality, new cardiac infarction cases, and necessity in myocardial revascularization [22-24]. A significant decrease in lethality resulted from patients taking aspirin as it was shown in ISIS-2 research [25]. When drugs that blocked P2Y12-recepotors of platelets (clopidogrel, ticagrelor) were added to aspirin, it led to even greater reduction in lethality $[26,27]$. ACE inhibitors were also thoroughly examined, and positive effects produced by them that caused greater decrease in lethality were described in detail [28, 29]. Nowadays they should be obligatory applied 
for treating patients suffering from CI with a rise in ST segment, with front CI, lower left ventricular ejection fraction, heart failure, arterial hypertension, and pancreatic diabetes. Beta-adrenoceptor blocking drugs reduce oxygen requirements by the cardiac muscle and improve blood flow redistribution from the epicardium to the cardiac muscle thus making an infarct zone smaller and stimulating patients' survival. Clinical research demonstrated a considerable decrease in lethality as well as reduced number of ventricular arrhythmia and less frequent recurrent infarctions [30]. These effects were persistent over a long-term period when beta-adrenoceptor blocking drugs were taken orally.

But still, patients' commitment to following recommendations given by their doctors remains rather poor. Meanwhile, there are data indicating that if a patient stops taking necessary medications after $\mathrm{CI}$, it results in higher morbid risks; for example, OR was equal to 1.82 after aspirin withdrawal; 1.96, beta-adrenoceptor blocking drugs withdrawal; 2.86, statins withdrawal; and 3.81 after three medications withdrawal (aspirin, beta-adrenoceptor blocking drug, and statin) [31]. Some authors consider poor commitment to treatment as a risk factor that can cause recurrent ischemic disasters. Thus, the above mentioned ACS register in Kemerovo region contains data on only $28.8 \%$ with recurrent CI who received double antithrombocytic therapy during a year; over a 5 -year period $22 \%$ patients didn't take statins, and $16 \%$ didn't take beta-adrenoceptor blocking drugs [16]. As per data taken from the Russian register RECORD, $18 \%$ patients who had CI stopped their treatment with double antithrombocytic therapy during the first year after the disease [32]. Research that focused on assessing commitment to therapy after Q-positive CI among Yakuts revealed a decrease in number of patients who took drugs by the end of the first year; thus, only $45 \%$ took aspirin; $40 \%$, a drug that blocked P2Y12-receptors of platelets; $41 \%$, beta-adrenoceptor blocking drugs; 33\%, ACE inhibitors/sartans; 39\%, statins [18].

Our research goal was to detect basic risk factors that could cause recurrent cardiovascu- lar disasters in patients during the first year after cardiac infarction in a big industrial city.

Data and methods. Our research object was Perm, a regional center with 1 million population, a territory with industrial and transport burdens being typical for Russia. We set the following basic criteria for patients to be included into our study: cardiac infarction diagnosed according to the Third universal definition of cardiac infarction [33]; absence of acute pathology, exacerbations of chronic diseases, arrhythmias, systemic diseases, and grave disorders in liver and kidneys functioning. To perform our study, we applied an original questionnaire. Overall, 40 patients were questioned; they all had had cardiac infarction from 3 to 12 months prior to the study (from September 2017 to July 2018) and were undergoing polyclinic rehabilitation. All participants permanently lived in Perm. We analyzed the following parameters: sex; age; applying to a doctor due to a cardiovascular disease (CVD) prior to $\mathrm{CI}$; time which passed since the first symptoms occurred till a patient applied for medical aid; revascularization procedure; what drugs were recommended by a doctor; whether a patient followed a doctor's recommendations or not; heredity; body mass index; physical activity; blood pressure; total cholesterol in blood; dextrose in blood; smoking status.

We assessed burdened heredity as per IHD cases in a patient's family which occurred in men younger than 55 and women younger than 65. BMI was calculated as per Quetelet formula. According to WHO recommendations, we considered BMI equal to $25-30 \mathrm{~kg} / \mathrm{m}^{2}$ an overweight; $30-35 \mathrm{~kg} / \mathrm{m}^{2}$, Obesity Class I; $35-40 \mathrm{~kg} / \mathrm{m}^{2}$, Obesity Class II, $40 \mathrm{~kg} / \mathrm{m}^{2}$ and more, Obesity Class III. Physical activity was considered to be low if a patient spent less than 30 minutes a day on it. Blood pressure equal to $\geq 140 / 90 \mathrm{~mm} \mathrm{Hg}$ meant a patient had arterial hypertension; if total cholesterol in blood was $\geq 4 \mathrm{mmol} / \mathrm{l}$, we considered that a patient had hypercholesterolemia given a very high risk of cardiovascular complications after $\mathrm{CI}$; dextrose in venous blood plasma equal to $\geq 6.1 \mathrm{mmol} / 1$ meant there was a disorder in dextrose level in blood plasma on an empty stomach. 
Characteristics of patients who had cardiac infarction $(n=40)$

\begin{tabular}{|c|c|c|}
\hline Parameter & Measure & \\
\hline \multirow[t]{2}{*}{ Sex } & men, \% & 55.0 \\
\hline & women, \% & 45.0 \\
\hline \multirow[t]{3}{*}{ Age (years) } & total, year & $65.7 \pm 9.9$ \\
\hline & men, years & $63.5 \pm 7.6$ \\
\hline & women, years & $68.3 \pm 12.0$ \\
\hline $\begin{array}{l}\text { Attended a doctor due to cardiac pathology prior } \\
\text { to cardiac infarction }\end{array}$ & share, $\%$ & 55.0 \\
\hline Cardiac infarction in case history & share, $\%$ & 15.0 \\
\hline Commitment to treatment before cardiac infarction & share, $\%$ & 63.6 \\
\hline $\begin{array}{l}\text { Average period of time that passed before a pa- } \\
\text { tient applied for a medical aid }\end{array}$ & hours & $111.5 \pm 201.0$ \\
\hline \multirow[t]{3}{*}{ Treatment tactics during hospitalization } & drug therapy, share, $\%$ & 40.0 \\
\hline & stenting, share, $\%$ & 55.0 \\
\hline & coronary artery bypass surgery, share, $\%$ & 5.0 \\
\hline Commitment to treatment after cardiac infarction & share, $\%$ & 45.0 \\
\hline \multirow[t]{7}{*}{ Risk factors } & burdened heredity, share, $\%$ & 65 \\
\hline & body mass index $\geq 25 \mathrm{~kg} / \mathrm{m}^{2}$, share, $\%$ & 68.4 \\
\hline & smoking, share, $\%$ & 15.0 \\
\hline & low physical activity, share, $\%$ & 25.0 \\
\hline & arterial hypertension, share, $\%$ & 43.75 \\
\hline & hypercholesterolemia, share, $\%$ & 55.6 \\
\hline & $\begin{array}{l}\text { dextrose in blood plasma on an empty } \\
\text { stomach }>6.1 \mathrm{mmol} / 1, \text { share, } \%\end{array}$ & 33.3 \\
\hline
\end{tabular}

Calculations and graphical analysis were performed with applied Microsoft Excel software. Quantitative parameters are given as a simple mean \pm standard deviation; qualitative parameters are given as frequencies in per cent.

Results and discussion. Table 1 contains an overall characteristics of patients who had cardiac infarction.

Men prevailed in this group of patients with $55 \%$ against $45 \%$ women. IHD revealed itself for the first time with CI in $45 \%$ patients and it is in line with data obtained in the country as a whole [34]. The first CI occurs in the first half of the 6th decade, or at $63.8 \pm 9.7$, and it usually happens a bit earlier to men (63.5 \pm 7.6$)$ than to women $(64.0 \pm 12.3$ лет). The obtained data are quite similar to sex and age structure of patients with CI included into RECORD 3 register in Perm region [35, 36].

A greater attention should be paid to insufficient primary PCI as only 55\% patients underwent such procedures. This is probably due to patients applying for medical aid too late when a lot of time has passed since the first symptoms occurred (Figure 1). About one third of patients are placed in a hospital after two or even more days and it is beyond a time span suitable for performing primary PCI [37].

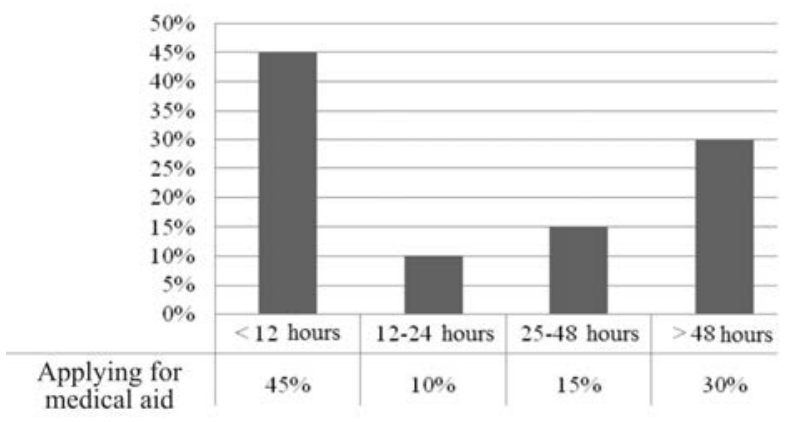

Figure 1. Time that passed from the first symptoms to a moment of applying for medical aid

We analyzed risk factors prevalence in patients during rehabilitation after $\mathrm{CI}$ and revealed that at least one risk factor was present in all of them. More than a half patients had burdened heredity as per cardiovascular dis- 
ease; one fourth had low physical activity in spite of not having any concomitant somatic pathology. Each seventh patient was an active smoker. $80 \%$ patients measured their blood pressure regularly and its values didn't correspond to the standard in half of them.

$60 \%$ patients knew dextrose level in their blood, but only $45 \%$ knew the figure for total cholesterol. One third of patients who controlled these parameters had disorders in dextrose level on an empty stomach, and more than a half of them had hypercholesterolemia. $31.6 \%$ patients had overweight; $10.5 \%$, Obesity Class I; $21.1 \%$, Obesity Class II; 5.3\%, Obesity Class III.

We analyzed patients' commitment to treatment and revealed that more than a half patients who had undergone CI didn't follow their doctors' recommendations. Men were less committed to treatment than women, with $41.7 \%$ against $50 \%$. Patients were the least committed to taking statins and drugs that blocked P2Y12-recetors of platelets (Figure 2). We should note that such drugs are recommended to be taken by all patients who had CI as opposed to, for example, ACE inhibitors as such drugs are to be taken only in some specific situations described above. As regards reasons for low commitment to treatment, we should highlight that more than one third of patients stated they were not sufficiently aware of the necessity to take drugs. Each fifth patient also mentioned that affordability of a drug was truly important (Figure 3).

Conclusions. So, patients who had cardiac infarction and who are undergoing polyclinic rehabilitation run high risks of recurrent cardiovascular disasters during the first year. An examined group of risk factors includes both factors that can't be modified and factors that can; among the latter we can mention such most frequent ones as low physical activity, overweight, hypercholesterolemia, and arterial hypertension. Such prevalence of risk factors indicates that secondary prevention activities are not efficient.

Conclusion. Efficient treatment of patients with CI during rehabilitation is truly vital nowadays and it should necessarily include

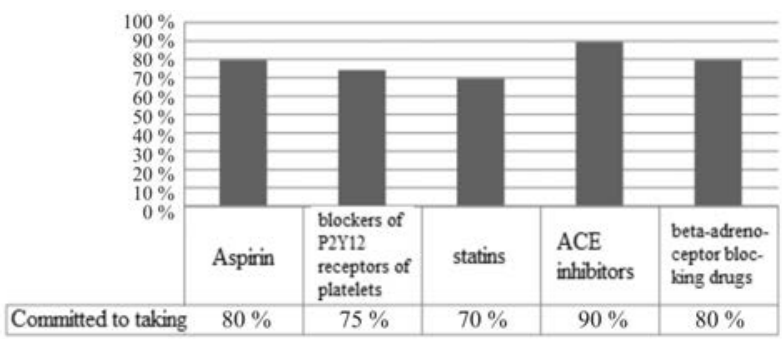

Figure 2. Patients' commitment to taking various drugs

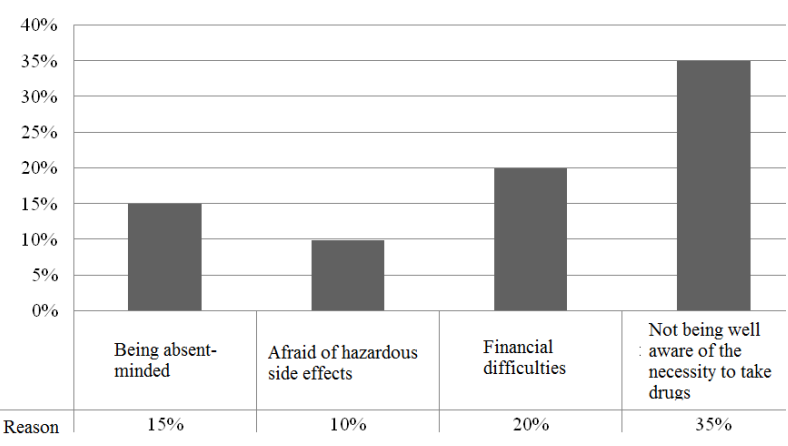

Figure 3. Reasons for low commitment to treatment

elimination or correction of risk factors that can cause recurrent cardiovascular disasters. Patients' life quality and long-term forecast of their survival depend on it to a great extent.

Low commitment to treatment, both before and after CI, is a basic problem related to secondary prevention. It occurs, first of all, due to doctors not giving their patients enough information about significance and necessity of taking drugs and correcting risk factors that can be modified.

Let us consider foreign experience in the sphere. Thus, in the USA highly qualified nurse practitioners are in great demand due to physicians being overloaded with work. Such specialists, in case of necessity, can provide uninterrupted observation over patients and make healthcare more available. First, a doctor examines a patient with CI after a release from a hospital. At this stage he or she determines what patients have the gravest problems, run risks of high co-morbidity and therefore need more frequent observation. A team approach to ambulatory care is applied to such patients; it means that highly qualified nurse practitioners help doctors monitor health of such patients and teach them how to pursue a healthier 
lifestyle. It can make for more efficient secondary prevention; in particular, greater commitment to taking statins was detected and more patients decided to give up smoking [38].

Similar practice was also implemented within Leonardo project in Apulia, Italy, where medical care managers, or specially trained nurses, took care of patients who suffered from grave chronic cardiovascular disease and pancreatic diabetes. Their responsibilities were to correct patients' lifestyle, to observe their health state and to provide them with necessary medical information. It resulted in great improvement of clinical parameters among patients who could now control their diseases more efficiently [39].

Low commitment to treatment is dealt with in Norway via greater inclusions of patients into cardiorehabilitation programs, more detailed information provided in leaflets given by general practitioners as regards risk factors, treatment goals, quantity and periodicity of visits to a doctor, as well as greater attention drawn to a smoking status of a patient [40].

In Taiwan great attention is paid to a period of time just after a release from a hospital as a patient is the most vulnerable during it [41]. A patient should visit a doctor during the first 7 days after a release from a hospital, and it should be noted, that in most cases a doctor who treated a patient in a hospital, continues to observe him or her afterwards. It helps to reduce a number of recurrent hospitalization as a doctor is better aware of some individual pecu- liarities a patient has and it also makes drug therapy more efficient.

These examples are quite interesting and can be implemented in Russia. Doctors in hospitals and polyclinics should pay greater attention to consulting their patients and clarifying treatment goals to them; they should give them written instructions with clear indication how often to visit a doctor, what changes to make in a lifestyle, and what drugs to take, and the effect will be better if a doctor and a patient first talk all these matters over, at least briefly. It is also advisable that a patient is attended to by the same doctor during the whole period of ambulatory care since it guarantees that this doctor is better aware about dynamics of a patient's state and knows what peculiarities a clinical course of the diseases has in this particular patient. If functional responsibilities carried by nurses are extended as regards observation over cardiologic patients who run higher risks, it can also be quite useful as it will allow to relieve doctors of some workloads and to provide greater commitment to treatment. Therefore, if we manage to optimize interaction between medical staff and patients, it will help to manage risks of recurrent cardiovascular disasters more efficiently.

Funding. The research was not granted any sponsor support.

Conflict of interests. The authors state there is no any conflict of interests.

\section{References}

1. Sulo E., Vollset S.E., Nygard O., Sulo G., Igland J.[et al.]. Trends in 28-day and 1-year mortality rates in patients hospitalized for a first acute myocardial infarction in Norway during 2001-2009: a "Cardiovascular disease in Norway" (CVDNOR) project. Journal of Internal Medicine, 2015, no. 277, pp. 353-361.

2. Koopman C., Bots M.L., van Oeffelen A.A., van Dis I., Verschuren W.M., Engelfriet P.M. [et al.]. Population trends and inequalities in incidence and short-term outcome of acute myocardial infarction between 1998 and 2007. International Journal of Cardiology, 2013, no. 168, pp. 993-998.

3. Schmidt M., Jacobsen J.B., Lash T.L., Botker H.E., Sorensen H.T. 25 year trends in first time hospitalisation for acute myocardial infarction, subsequent short and long term mortality, and the prognostic impact of sex and comorbidity: a Danish nationwide cohort study. BMJ, 2012, vol. 344, pp. 356-364.

4. Dudas K., Lappas G., Rosengren A. Long-term prognosis after hospital admission for acute myocardial infarction from 1987 to 2006. International Journal of Cardiology, 2012, no. 155, pp. 400-405. 
5. Strelchenko O.V. Osnovnye pokazateli zdorov'ya naseleniya i zdravookhraneniya Sibirskogo federal'nogo okruga v 2012 godu. Sbornik statisticheskikh i analiticheskikh materialov. [The main indicators of public health and health care of the Siberian Federal District in 2012. Digest of statistical and analytical materials. Release 12]. Novosibirsk: Ofset, 2013, pp. 332 (in Russian).

6. Wagner S., Burczyk U., Schiele R. [et al.]. The 60 minutes myocardial infarction project: characteristics on admission and clinical outcome in patients with reinfarction compared to patients with a first infarction. European Heart Journal, 1998, no. 19, pp. 879-884.

7. Natali A., Vichi S., Landi P. [et al.]. Mortality from coronary heart disease in subjects with type 2 diabetes and in non-diabetic subjects with and without prior myocardial infarction. The New England Journal of Medicine, 1998, no. 339, pp. 229-234.

8. Motivala A.A., Tamhane U., Ramanath V.S. [et al.]. A prior myocardial infarction: how does it affect management and outcomes in recurrent acute coronary syndromes? Clinical Cardiology, 2008, no. 31, pp. 590-596.

9. Volkova E.G., Malykhina O.P., Levashov S.Yu. Povtornye infarkty miokarda: osobennosti izmeneniya soderzhaniya biomarkerov i remodelirovaniya miokarda (issledovanie sluchai-kontrol'). Kardiologiya, 2007, no.7, pp. 26-28 (in Russian).

10. Shiraishi J., Kohno Y., Sawada T. [et al.]. Predictors of in-hospital outcome after primary percutaneous coronary intervention for recurrent myocardial infarction. Circulation Journal, 2008, no. 72 , pp. $1225-1229$.

11. Shotan A., Blondheim D.S., Gottlieb S. [et al.]. Comparison of outcome of recurrent versus first ST-segment elevation myocardial infarction (from National Israel Surveys 1998 to 2006). American Journal of Cardiology, 2011, no. 107, pp. 1730-1737.

12. Antman E.M., Cohen M., Bernink P.J. [et al.]. The TIMI risk score for unstable angina/nonST elevation MI: A method for prognostication and therapeutic decision making. The Journal of the American Medical Association, 2000, vol. 284, no. 7, pp. 835-842.

3. Boersma E., Pieper K.S., Steyerberg E.W. [et al.]. Predictors of outcome in patients with acute coronary syndromes without persistent ST-segment elevation. Results from an international trial of 9461 patients. The PURSUIT Investigators. Circulation, 2000, vol. 101, no. 22, pp. 2557-2567.

14. Fox K.A., Dabbous O.H., Goldberg R.J. [et al.]. Prediction of risk of death and myocardial infarction in the six months after presentation with acute coronary syndrome: prospective multinational observational study (GRACE). BMJ, 2006, vol. 333, no. 7578, pp. 1091-1094.

15. Eagle K.A., Lim M.J., Dabbous O.H. [et al.]. A validated prediction model for all forms of acute coronary syndrome: estimating the risk of 6-month postdischarge death in an international registry. The Journal of the American Medical Association, 2004, vol. 291, no. 22, pp. 2727-2733.

16. Barbarash O.L., Sedykh D.Yu., Gorbunova E.V. Osnovnye faktory, opredelyayushchie risk razvitiya povtornogo infarkta miokarda // Serdtse: zhurnal dlya praktikuyushchikh vrachei, 201, vol. 16 , no. 1 , pp. 10-50 (in Russian).

17. Negmadzhonov U.U., Kuimov A.D. Povtornye infarkty miokarda: faktory riska, klinika, lechenie [Recurrent myocardial infarction: risk factors, clinic, treatment]. Meditsina i obrazovanie $v$ Sibiri: elektronnyi nauchnyi zhurnal, 2011, no. 6. Available at: http://www.ngmu.ru/cozo/mos/article/text full.php?id=548 (23.12.2018) (in Russian).

18. Kylbanova E.S., Gur'eva E.V., Pavlova A.V. Chastota vstrechaemosti faktorov riska i priverzhennost' k medikamentoznoi terapii u yakutov, perenesshikh Q-pozitivnyi infarkt miokarda [The frequency of occurrence of risk factors and adherence to drug therapy in Yakuts who had Q-positive myocardial infarction]. Arhiv vnutrennei meditsiny, 2018, vol. 8, no. 4, pp. 291-299 (in Russian).

19. Myftiu S., Sulo E., Burazeri G. [et al.]. Clinical profile and management of patients with incident and recurrent acute myocardial infarction in Albania - a call for more focus on prevention strategies. Slovenian Journal of Public Health, 2017, vol. 56, no. 4, pp. 236-243.

20. Cao C-F., Li S-F., Chen H., Song J-X. Predictors and in-hospital prognosis of recurrent acute myocardial infarction. Journal of Geriatric Cardiology, 2016, vol. 13, no. 10, pp. 836-839.

21. Janzon M., Henriksson M., Hasvold P. [et al.]. Long-term resource use patterns and healthcare costs after myocardial infarction in a clinical practice setting: results from a contemporary na- 
tionwide registry study. European Heart Journal - Quality of Care and Clinical Outcomes, 2016, vol. 2, no. 4, pp. 291-298.

22. Scandanavian Simvastatin Survival Study Group. Randomised trial of cholesterol lowering in 4444 patients with coronary heart disease: the Scandinavian Simvastatin Survival Study (4S). Lancet, 1994, vol. 344, pp. 1383-1389.

23. Tonelli M., Moyé L. [et al.]. Effect of pravastatin on loss of renal function in people with moderate chronic renal insufficiency and cardiovascular disease. American Society of Nephrology, 2003, no. 14, pp. 1605-1613.

24. The long-term intervention with pravastatin in ischaemic disease (LIPID) study group. Prevention of cardiovascular events and death with prevastatinin patients with coronary heart disease and a broad range of initial cholesterol levels. The New England Journal of Medicine, 1998, no. 339, pp. 1349-1357.

25. ISIS-2 collaborative group. Randomised trial of intravenous streptokinase, oral aspirin, both, or neither among 17187 cases of suspected acute myocardial infarction. Lancet, 1988, vol. 332, no. 8607 , pp. 349-360.

26. Steinhubl S.R., Berger P.B., Mann J.T. [et al.]. Early and sustained dual oral antiplatelet therapy following percutaneous coronary intervention: a randomized controlled trial. The Journal of the American Medical Association, 2002, no. 288, pp. 2411-2420.

27. Berger J.S. Aspirin, clopidogrel, and ticagrelorin acute coronary syndromes. American Journal of Cardiology, 2013, no.112, pp. 737-745.

28. The acute infarction ramipril efficacy (AIRE) study investigators. Effect of ramipril on mortality and morbidity of survivors of acute myocardial infarction with clinical evidence of heart failure. Lancet, vol. 342, no. 8875, pp. 821-828.

29. HOPE (Heart Outcomes Prevention Evaluation) study investigators. Effects of an angiotensinconverting-enzyme inhibitor, ramipril, on cardiovascular events in high-risk patients. The New England Journal of Medicine, 2000, no. 342, pp. 145-153.

30. Teo K.K., Yusuf S. Furberg C.D. Effects of prophylactic antiarrhythmic drug therapy in acute myocardial infarction. An overview of results from randomized controlled trials. The Journal of the American Medical Association, 1993, no. 270, pp. 1589-1595.

31. Spertus J.A., Masoudi F.A., Reid K.J. [et al.]. Impact of medication therapy discontinuation on mortality after myocardial infarction. Archives of Internal Medicine, 2006, vol. 166, no.17, pp. 1842-1847.

32. Erlikh A.D. Dvoinaya antitrombotsitarnaya terapiya: neobkhodimost' priverzhennosti k lecheniyu i vozmozhnosti ee povysheniya [Dual antiplatelet therapy: the need for adherence to treatment and the possibility of its increase]. Aterotromboz, 2014, no. 2, pp. 25-33 (in Russian).

33. Thygesen K., Alpert J.S., Jaffe A.S. [et al.]. Third Universal Definition of Myocardial Infarction. Circulation, 2012, no. 126, pp. 2020-2035.

34. Nauchnaya platforma «profilakticheskaya sreda» [Scientific platform "Preventive environment], 2013. Available at: http://www.gnicpm.ru/UserFiles/prof_sreda_bazis_posl_variant.pdf (23.09.2018) (in Russian).

35. Dultsev K.N., Lapin O.M., Oschepkova M.A., Syromyatnikova L.I., Yunusov E.M., Chizhova A.A. Puti optimizatsii okazaniya meditsinskoi pomoshchi bol'nym s ostrym koronarnym sindromom (po dannym gospital'nogo etapa registra "Rekord-3") [Ways for optimization of rendering medical care to patients with acute coronary syndrome (by hospital register "Record-3" data)]. Sovremennye problemy nauki i obrazovaniya, 2015, no. 5, p. 196 (in Russian).

36. Lapin O.M. Sravnitel'nyi analiz rezhimov reperfuzionnoi terapii v lechenii bol'nykh infarktom miokarda s pod"emom segmenta ST v usloviyakh real'noi klinicheskoi praktiki [Comparative analysis of reperfusion therapy regimes in management of patients with ST segment elevation myocardial infarction in conditions of real clinical practice]. Sovremennye problemy nauki $i$ obrazovaniya, 2015, vol. 32, no. 5, pp. 37-43 (in Russian).

37. Ibanez B. [et al.]. 2017 ESC Guidelines for the management of acute myocardial infarction in patients presenting with ST-segment elevation. The Task Force for the management of acute 
myocardial infarction in patients presenting with ST-segment elevation of the European Society of Cardiology (ESC). European Heart Journal, 2017, no. 00, pp. 1-66.

38. Rymer J.A., Chen A.Y., Thomas L. [et al.]. Advanced practice provider versus physicianonly outpatient follow-up after acute myocardial infarction. Journal of the American Heart Association, 2018, vol. 7, no. 17.

39. Ciccone M.M., Aquilino A., Cortese F. [et al.]. Feasibility and effectiveness of a disease and care management model in the primary health care system for patients with heart failure and diabetes (Project Leonardo). Vascular health and risk management, 2010, no. 6, pp. 297-305.

40. Munkhaugen J., Peersen K., Sverre E. [et al.]. The follow-up after myocardial infarction is it good enough? Journal of the Norwegian Medical Association, 2018, vol. 138, no. 5.

41. Tung Y.C., Chang G.M., Chang H.Y., Yu T.H. Relationship between early physician follow-up and 30-day readmission after acute myocardial infarction and heart failure. PLoS One, 2017, vol. 12 , no. 1 .

Novikova I.A., Nekrutenko L.A., Lebedeva T.M., Kchlynova O.V., Shishkina E.A. PATIENT After cardiac infarction: risk factors that can cause new cardiovascular disasters. Health Risk Analysis, 2019, no. 1, pp. 135-143. DOI: 10.21668/health.risk/2019.1.15.eng

Received: 06.11.2018

Accepted: 24.02 .2019

Published: 30.03 .2019 